\title{
Prevalence of Long COVID symptoms in Bangladesh: A Prospective Inception Cohort Study of COVID-19 survivors.
}

Mohammad Anwar Hossain ${ }^{1,8}$, K M Amran Hossain², Karen Saunders ${ }^{3,7,9}$, Zakir Uddin ${ }^{4}$, Lori Maria Walton ${ }^{5}$, Veena Raigangar ${ }^{6}$, Mohamed Sakel ${ }^{7,9}$, Rubayet Shafin ${ }^{8}$, Mohammad Sohrab Hossain $^{2}$, Md. Feroz Kabir ${ }^{9}$, Rafey Faruqui ${ }^{10,11}$, Shohag Rana ${ }^{2}$, Md. Shahoriar Ahmed ${ }^{8}$ Sonjit Kumar Chakrovorty ${ }^{1}$, Md. Anwar Hossain, ${ }^{12,13}$, and Iqbal Kabir Jahid ${ }^{1 *}$

${ }^{1}$ Department of Microbiology, Jashore University of Science \& Technology (JUST), Jashore, Bangladesh

${ }^{2}$ Department of Physiotherapy, Bangladesh Health professions Institute (BHPI), Dhaka, Bangladesh

${ }^{3}$ School of Social Policy, Sociology and Social Research, University of Kent, Canterbury, UK ${ }^{4}$ School of Rehabilitation Science, McMaster University, 1400 Main St W, Hamilton, ON, L8S 1C7, Canada

${ }^{5}$ Department of Physical Therapy, School of Health Sciences, University of Scranton, Pennsylvania, USA

${ }^{6}$ Department of Physiotherapy, College of Health Sciences, University of Sharjah, Sharjah, U.A.E

${ }^{7}$ East Kent Hospitals University NHS Foundation Trust, Canterbury, Kent, UK

${ }^{8}$ Department of Physiotherapy, Centre for the Rehabilitation of the Paralysed (CRP), Savar, Dhaka, Bangladesh

${ }^{9}$ Department of Physiotherapy \& Rehabilitation, Jashore University of Science \& Technology (JUST), Jashore, Bangladesh

${ }^{10}$ Department of Neuropsychiatry. Kent \& Medway NHS Social Care Partnership Trust, UK

${ }^{11}$ Centre for Health Services Studies, University of Kent, Canterbury, UK

${ }^{12}$ Department of Microbiology, University of Dhaka, Dhaka, Bangladesh

${ }^{13}$ Vice Chancellor, Jashore University of Science and Technology (JUST), Jashore, Bangladesh

*Correspondence ikjahid_mb@just.edu.bd 
medRxiv preprint doi: https://doi.org/10.1101/2021.07.03.21259626; this version posted July 6, 2021. The copyright holder for this preprint (which was not certified by peer review) is the author/funder, who has granted medRxiv a license to display the preprint in perpetuity. It is made available under a CC-BY-NC 4.0 International license.

\begin{abstract}
Objective

The objective of this study was to identify the prevalence of 'Long COVID' symptoms (LCS) in a large cohort of survivors and identify any potential associated risk factors.
\end{abstract}

\title{
Design
}

A prospective survey was undertaken of an inception cohort of confirmed COVID-19 survivors (Aged 18 to 87 years).

\section{Participants and Setting}

14392 participants were recruited from 24 testing facilities across Bangladesh between June, and November 2020. All participants had a previously confirmed positive COVID-19 diagnosis, and reported persistent symptoms and difficulties in performing daily activities.

\section{Main Outcome Measures}

Participants who consented, were contacted by face-to-face interview, and were interviewed regarding LCS, and restriction of activities of daily living using Post COVID-19 functional scale. Cardio-respiratory parameters were also measured.

\section{Results}

Among 2198 participants, the prevalence of LCS at 12 weeks was 16.1\%. Overall, eight LCS were identified and in descending order of prominence are: fatigue, pain, dyspnea, cough, anosmia, appetite loss, headache, and chest pain. COVID survivors experienced between 1 to 5 LCS with an overall duration period of $21.8 \pm 5.2$ weeks. SEM predicted the length of LCS to be related to younger age, female gender, rural residence, prior functional limitation and smoking.

\section{Conclusion}

In this cohort of survivors, at 31 weeks post diagnosis, the prevalence of LCS was $16.1 \%$. The risk factors identified for presence and longer length of LCS warrant further research and consideration to support public health initiatives.

Keywords: Long COVID Symptoms, Post-acute COVID-19 syndrome, Post COVID-19 syndrome, Bangladesh 
medRxiv preprint doi: https://doi.org/10.1101/2021.07.03.21259626; this version posted July 6, 2021. The copyright holder for this preprint (which was not certified by peer review) is the author/funder, who has granted medRxiv a license to display the preprint in perpetuity. It is made available under a CC-BY-NC 4.0 International license.

\section{Introduction}

Individual recovery from COVID-19 infection varies, and it is not fully understood why some people experience persistent symptoms over a longer time period than others. Post-acute COVID-19 syndrome ${ }^{1}$ (PACS)and Post-COVID-19 syndrome ${ }^{2}$ are terms used clinically to describe ongoing or new symptoms that occur after the fourth week of recovery from an acute infection, that cannot be explained by an alternative medical diagnosis. The experience of longer-term symptoms has prompted some patient groups to invent and use the term "Long COVID" 3 to describe their experience of ongoing symptoms, that persist beyond four weeks from suspected infection or positive diagnosis to over 12 weeks and longer. It is now understood that COVID-19 can impact on multiple organ systems ${ }^{4}$, which can lead to a diverse range of persistent symptoms including fatigue, breathlessness, cough, loss of taste and/or smell, myalgia, memory issues and gastrointestinal problems. ${ }^{5-6}$ An integrative post COVID symptom model was recently proposed for symptom classification after confirmed diagnosis of COVID-197 This model incorporates reference to the "relapsing remitting" ${ }^{\prime}$ pattern of symptoms experienced by many survivors and has been adopted to assist in presentation of results.

A large recent survey conducted over a four-week period in the UK found that 1.1 million people self-reported "long COVID" symptoms (LCS), which equates to $1.7 \%$ of the population. ${ }^{9}$ The survey also identified that $18.1 \%$ of participants reported that their daily activities had been affected a lot by the illness, indicating that "Long COVID" has a detrimental impact on peoples' day to day lives, so should be taken seriously. ${ }^{10}$

It is acknowledged that there is a need for further research into the prevalence and duration of LCS experienced by survivors ${ }^{11}$ and potential associated risk factors so that overall clinical management can be improved ${ }^{12}$. This is especially pertinent in Low to Middle Income Countries $^{13}$ like Bangladesh, where the majority of the population live in rural districts ${ }^{14}$ outside of the densely populated capital city, Dhaka. There are only two published studies so far in Bangladesh on persistent symptoms following COVID-19 infection. One survey of 1002 individuals reported that $20 \%$ had experienced persisting symptoms after COVID-19, with diarrhea (12.7\%) being most common followed by fatigue $(11.5 \%) .{ }^{15} \mathrm{~A}$ second smaller study of 355 individuals found that $46 \%$ of patients recovering from COVID19 reported $\operatorname{LCS}^{16}$ with fatigue being the most common symptom reported. Therefore, it is critical to gain research knowledge on the prevalence of LCS and identify associated risk factors, as this study does, which will be of relevance to the global community. 
medRxiv preprint doi: https://doi.org/10.1101/2021.07.03.21259626; this version posted July 6, 2021. The copyright holder for this preprint

(which was not certified by peer review) is the author/funder, who has granted medRxiv a license to display the preprint in perpetuity.

It is made available under a CC-BY-NC 4.0 International license .

The aim of this study was to identify the prevalence of LCS in Covid-19 survivors and explore any potential associations between reported symptoms and the independent variables measured. Cardio-respiratory parameters and functional restrictions were also measured to try to discern if there was an impact on the cardiac system and if functional daily activities were affected by LCS.

\section{Methods}

Study design and participants

This prospective study utilized an inception cohort of adult COVID-19 survivors recruited from a large population sample frame of 14392 COVID positive cases. These cases were identified from 24 testing facilities across Bangladesh between June and November 2020. All COVID-19 positive and negative diagnoses were performed using a RT-PCR test (Real time polymerase chain reaction test $)^{17}$. Inclusion criteria were: age 18 years and over; people who reported persistent symptoms after positive diagnosis and people who reported difficulties in undertaking usual daily activities. Exclusion criteria were: individuals too sick to participate; those who declined consent and those we were unable to contact.

The sample size calculation was performed using "EPI INFO" software version 7.4.2.0 developed by the Center for Disease Control in the US. For the calculation, the reference figure of 535,139 was used (ie. The total number of COVID-19 positive cases reported up to January 2021) ${ }^{18}$ with a cluster figure of eight (the number of administrative divisions in Bangladesh) A calculation was then made with $50 \%$ of expected frequency, $5 \%$ margin of error, and 1.0 design effect. The sample size was generated as a minimum of 1088 with a minimum of 136 samples per division.

Study procedure

A clear flow diagram of the study process has been produced in Figure 1 to meet the quality guidelines recommended by Strengthening the Reporting of Observational studies in Epidemiology (STROBE) $)^{20}$.

Data was collected by eight trained data collectors from the Centre for the Rehabilitation of the Paralyzed (CRP). Data collectors were comprehensively trained by the study team regarding study aims, ethical considerations, questionnaires and clinical outcome measures. Screening for trial eligibility and consent for data collection was conducted using mobile telephones. Face to face data collection was undertaken via mutually convenient scheduled 
medRxiv preprint doi: https://doi.org/10.1101/2021.07.03.21259626; this version posted July 6 , 2021. The copyright holder for this preprint (which was not certified by peer review) is the author/funder, who has granted medRxiv a license to display the preprint in perpetuity.

It is made available under a CC-BY-NC 4.0 International license .

appointments either in the respondent's house or workplace. All data collectors adhered scrupulously to the COVID-19 preventative precautions, use of personal protective equipment (PPE) and health regulations. Consent and questionnaire documents were provided as hard paper copies in Bengali for respondents to complete themselves. If there was a literacy issue then data collectors provided support with this to enable completion. Data was then collated anonymously from these documents and transferred into an Excel workbook for audit and analysis. A small-scale pilot study using 17 respondents was initially conducted to test applicability and feasibility of the questionnaire. 
medRxiv preprint doi: https://doi.org/10.1101/2021.07.03.21259626; this version posted July 6,2021 . The copyright holder for this preprint (which was not certified by peer review) is the author/funder, who has granted medRxiv a license to display the preprint in perpetuity.

It is made available under a CC-BY-NC 4.0 International license .

Figure 1: STROBE flow diagram of the study

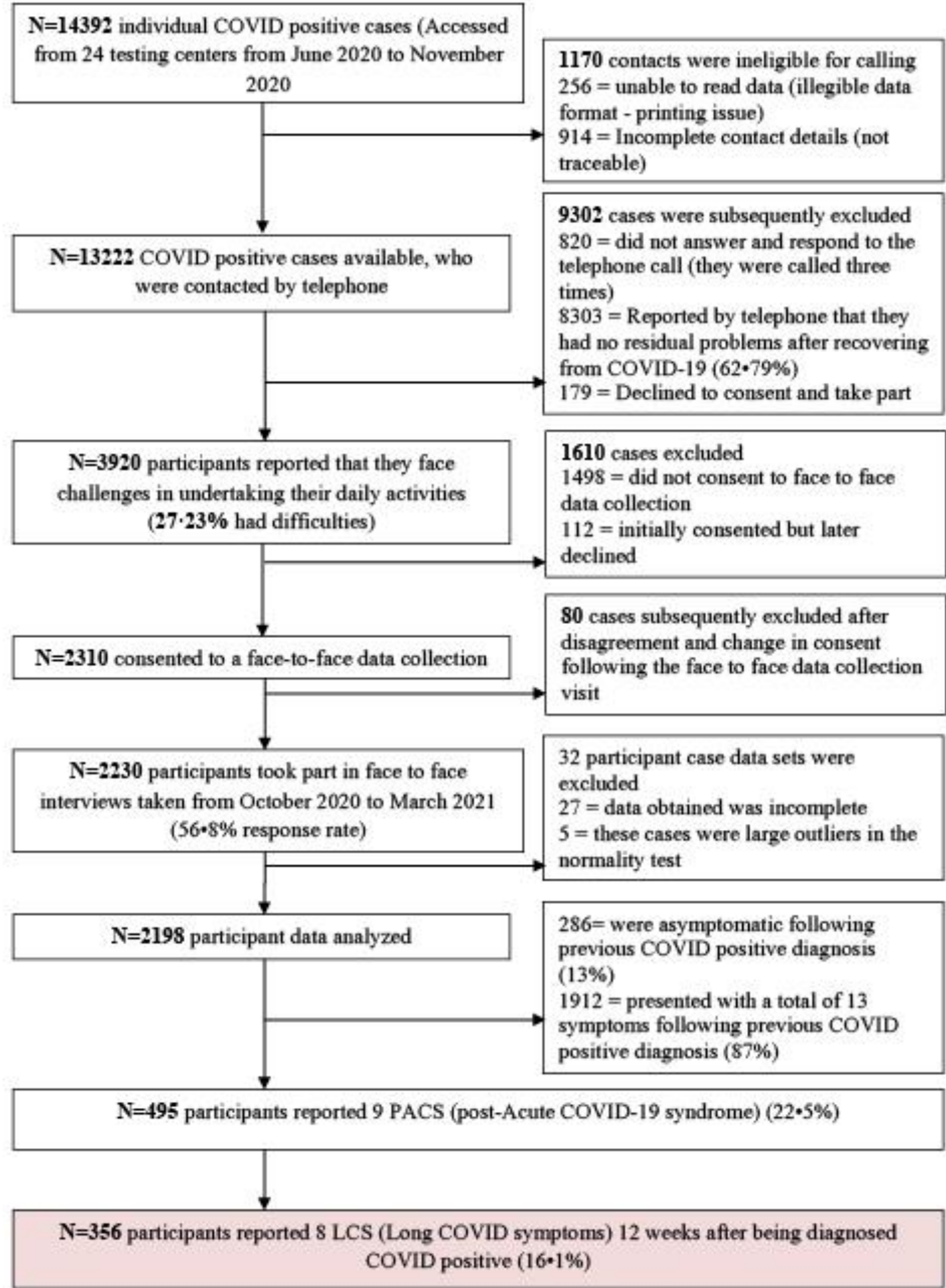


medRxiv preprint doi: https://doi.org/10.1101/2021.07.03.21259626; this version posted July 6, 2021. The copyright holder for this preprint (which was not certified by peer review) is the author/funder, who has granted medRxiv a license to display the preprint in perpetuity. It is made available under a CC-BY-NC 4.0 International license.

\section{Data collection and Questionnaire}

All contactable participants $(\mathrm{N}=13,222)$ were asked by telephone: "Do you feel that you have any challenges or have any persisting symptoms after receiving a negative test result for COVID-19?" Participants who consented to face to face data collections ( $\mathrm{N}=2310)$ were provided with a questionnaire consisting of three parts. The first part was designed to gather socio demographic information with seven questions related to age, gender, marital status, education, residing area, and occupation. The second part consisted of seven questions related to comorbidities, blood group and rhesus status, date of COVID-19 positive test, date of COVID-19 negative test, presenting symptoms during COVID-19 illness, persisting COVID19 symptoms, and treatment received during COVID-19 illness. The third part of the questionnaire focused on the measurement of cardio-respiratory parameters and included the Post COVID-19 Functional Status Scale ${ }^{21}$ (PCFS). Cardio-respiratory parameters measured included: resting heart rate (HR); blood oxygen saturation levels (Spo2); systolic and diastolic blood pressure; inspiratory and expiratory lung volumes; and maximal oxygen consumption (Vo2max).

The PCFS is an instrument that aims to identify and record the course of symptoms following infection with COVID-19 and their impact on the abilities of the recovering individual. The scale covers six domains including: survival; constant care; basic activities of daily living; instrumental activities of daily living; participation in usual social roles and a symptom checklist. Each item in each domain is scored from five possible options on an ordinal scale from zero to four with the fifth grade being "Death". An overall final scale grade is obtained from completion with a high-grade corresponding to more functional limitations and a low final grade indicates no persisting symptoms or restricted daily activities. The PCFS has adequate construct validity ${ }^{22}$ and has a Cronbach alpha score of $\alpha 0.879$ in our study, which indicates a satisfactory level of internal consistency. The PCFS was translated into Bengali and the language validation process was followed as per WHO guidance. ${ }^{23}$

\section{Statistical Testing}

Data analysis utilized the statistical software package for social sciences (SPSS) version 20.0. The normality test was performed through Kolmogorov-Smirnov test. Descriptive statistics were performed separately for Acute COVID-19 Symptoms (ACS), PACS and the LCS groups (Tables 1 and 2). Relationships between a categorical independent variable (for example, LCS) and a parametric socio-demographic dependent variable were determined through independent $\mathrm{t}$ tests. In addition, relationships among two or more categorical 
medRxiv preprint doi: https://doi.org/10.1101/2021.07.03.21259626; this version posted July 6, 2021. The copyright holder for this preprint (which was not certified by peer review) is the author/funder, who has granted medRxiv a license to display the preprint in perpetuity. It is made available under a CC-BY-NC 4.0 International license.

variables were explored using the chi-square test (Table 2). To ascertain which factors were potentially related to LCS, binary logistic regression was performed with the presence of LCS as the dependent variable (Table 3) and multiple linear regressions were performed with the duration of LCS as the dependent variable (Table 4). Figures 3, 5 and 6 are presented as bar charts with an error bar $(95 \% \mathrm{CI})$. Figure 7 presents the associated risk factors identified for LCS using Structural Equation Modeling (SEM) using SPSS AMOS version 24.0 (Figure 7). The alpha value was set as $\mathrm{p}<.05$.

Patient and Public Involvement

Researchers invited the COVID-19 survivors from the list supplied by the government via telephone call before starting the face-to-face data collection. After preliminary screening, the eligible participants were listed separately and further contacted (Figure 1). Data was collected at the participant's home or office with written consent. Participants had briefly demonstrated the study process, voluntary agreement and assured the confidentiality of their information by the data collectors during face-to-face interview. The patients declared their involvement and communication was willing, voluntary and had no objection to use the data for research purpose. The process of finding the contacts of the COVID-19 survivors, contacting them and perform data collection in this pandemic were permitted and approved by the appropriate authority of the Government of the People's Republic of Bangladesh.

\section{Results}

Prevalence

From 14392 estimated samples, 13222 respondents were called by telephone.62.79\% (8303) COVID survivors reported complete recovery and $27.23 \%$ (3920) stated that they faced difficulties when undertaking daily activities. The study had a reasonably good response rate of $56.8 \%$. This study found that $22.5 \%$ (495) of COVID survivors had PACS at 4 weeks post diagnosis and $16.1 \%$ (356) had LCS at 12 weeks post diagnosis (Figure 1).

\section{Socio-demographic variables and health related information}

The mean age of all ACS $(n=2198)$ was $38.07 \pm 11.4$ years, survivors with PACS $(n=495)$ $38.86 \pm 11.3$ and those survivors with LCS $(n=356)$ had mean age $38.42 \pm 11$. . The majority of the ACS were between 31 and 40 years of age $43.3 \%$ (718) and 30.4\% (669) were aged 18-30 years. The male to female ratio of the respondents was 2.6:1. Respondents covered all eight 
medRxiv preprint doi: https://doi.org/10.1101/2021.07.03.21259626; this version posted July 6, 2021. The copyright holder for this preprint (which was not certified by peer review) is the author/funder, who has granted medRxiv a license to display the preprint in perpetuity. It is made available under a CC-BY-NC 4.0 International license.

administrative divisions in Bangladesh as follows: Dhaka 35.89\% (789), Chittagong 8.50\% (187), Rajshahi 8.37\% (184), Sylhet 9.63\% (212), Rangpur 9.13\% (201), Barisal 10.62\% (234), Khulna 8.04\% (177) and Mymensingh 9.73\% (214). There was a larger number of responses from rural areas $75.2 \%$ (1652). 85\% (1868) of the participants were married and $50.1 \%$ (1101) were graduate or postgraduate. The most common occupation reported was that of private jobs, which comprised $55.1 \%$ (1212). Multiple response analyses found that the most common comorbidities for ACS were as follows: $22.7 \%$ had diabetes, $25.6 \%$ had hypertension, $6 \%$ had heart disease, and $6.9 \%$ had pre-existing lung disease $34.7 \%$ of the ACS had blood group B positive and other major distributions were $\mathrm{O}$ positive $23.4 \%$, and $\mathrm{A}$ positive $23.1 \%$. The detailed socio-demographic and health related information for participants is appended in Table 1.

\section{Symptom responses and duration}

Figure 2 presents the results using the integrative post COVID symptoms model ${ }^{7}$ and identifies that amongst the ACS13\% (286) were asymptomatic. Amongst those with symptoms, the most common symptoms described were fever $76.6 \%$ (1683), fatigue $50.1 \%$ (1101), cough and upper respiratory tract symptoms 65.4\% (1438), dyspnea $23.8 \%$ (523), pain $33.1 \%$ (727), ageusia 29.3\% (644), headache 38\% (836), and anosmia 43.9\% (966). After four weeks, the major PACS were fatigue 84.8\% (420), and pain 15.4\% (76). After 12 weeks, LCS presented as fatigue $82.9 \%$ (295), cough and upper respiratory tract symptoms $8.7 \%$ (31), dyspnea $10.4 \%$ (37), pain $16.9 \%$ (60), chest pain .3\% (1), ageusia3.4\% (12), headache $2.2 \%(8)$ and anosmia5.1\% (18). Fatigue was the prominent LCS. The number of LCS experienced by a COVID survivor ranged from 1 to 5 (Figure 3). The overall duration of LCS was 21.8 \pm 5.2 weeks. Duration of individual LCS varied in weeks as follows: fatigue 21.7 \pm 5.2 ; pain22.2 \pm 5.3 ; dyspnea22.7 \pm 4.9 ; cough and upper respiratory symptoms $22.4 \pm 5.1$; anosmia 22.6 \pm 6 , ageusia20.6 \pm 5.5 and headache $22.5 \pm 5.7$. There was a relapsing remitting pattern noted in the LCS from week 13 onwards to week 31, with the highest increments of LCS noted from 25th to 26th week (Figure 4). 
Figure 2: Acute COVID-19 Symptoms (ACS), Post-Acute COVID-19 symptoms (PACS) and Long COVID Symptom (LCS) responses

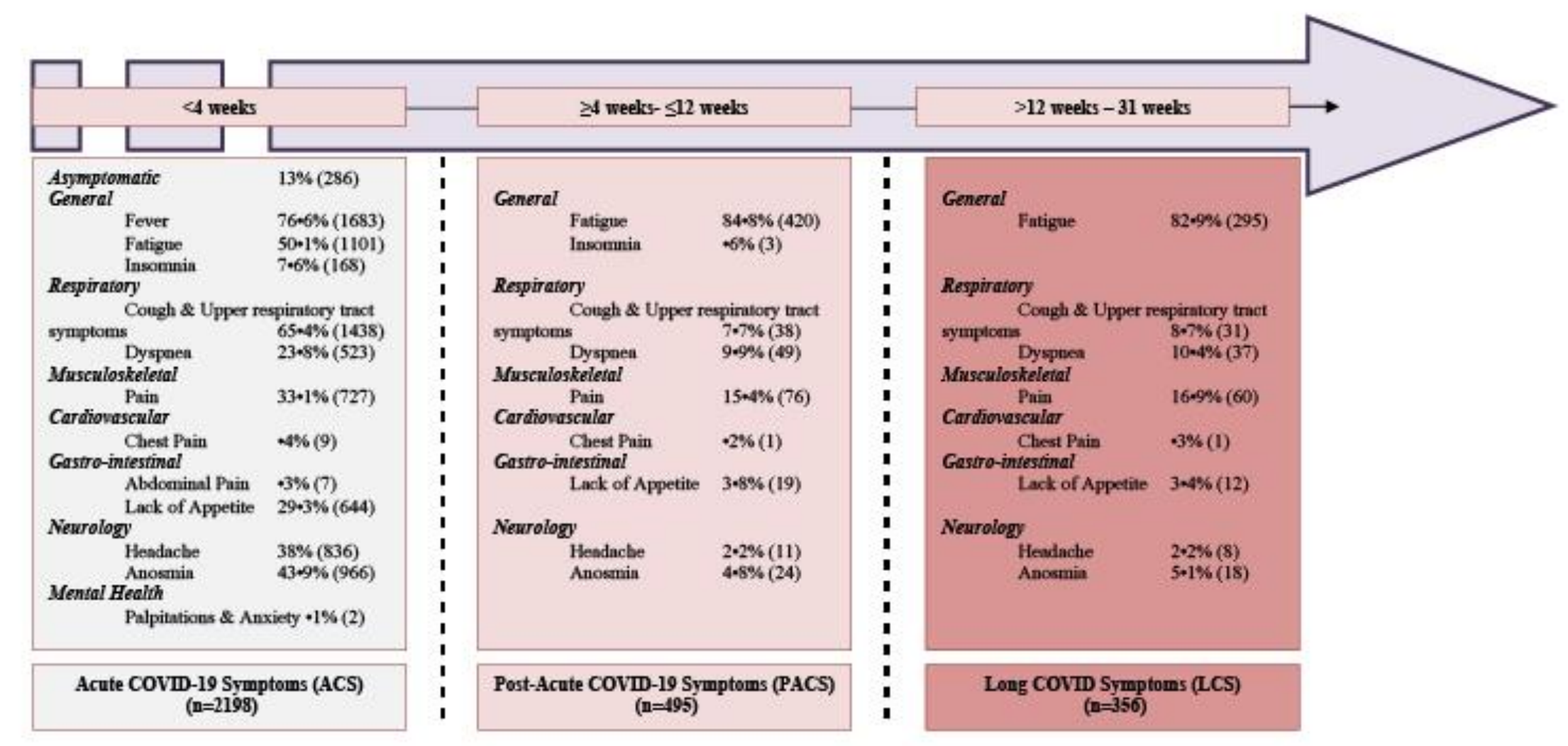


medRxiv preprint doi: https://doi.org/10.1101/2021.07.03.21259626; this version posted July 6,2021 . The copyright holder for this preprint (which was not certified by peer review) is the author/funder, who has granted medRxiv a license to display the preprint in perpetuity. It is made available under a CC-BY-NC 4.0 International license .

Figure 3: Distribution of Long COVID Symptom (LCS)
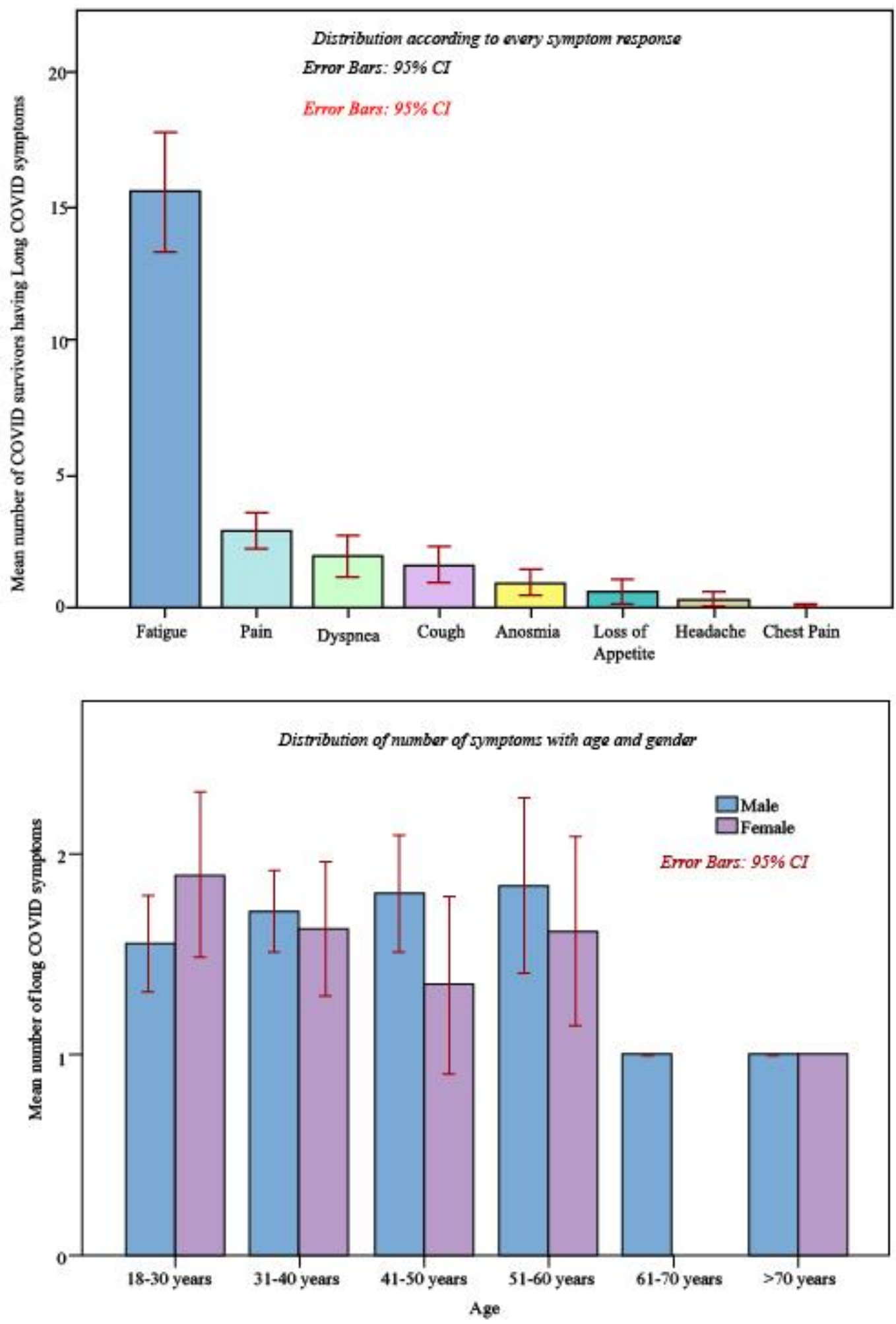
Figure 4: Relapsing Remittent pattern of Long COVID symptom (LCS)

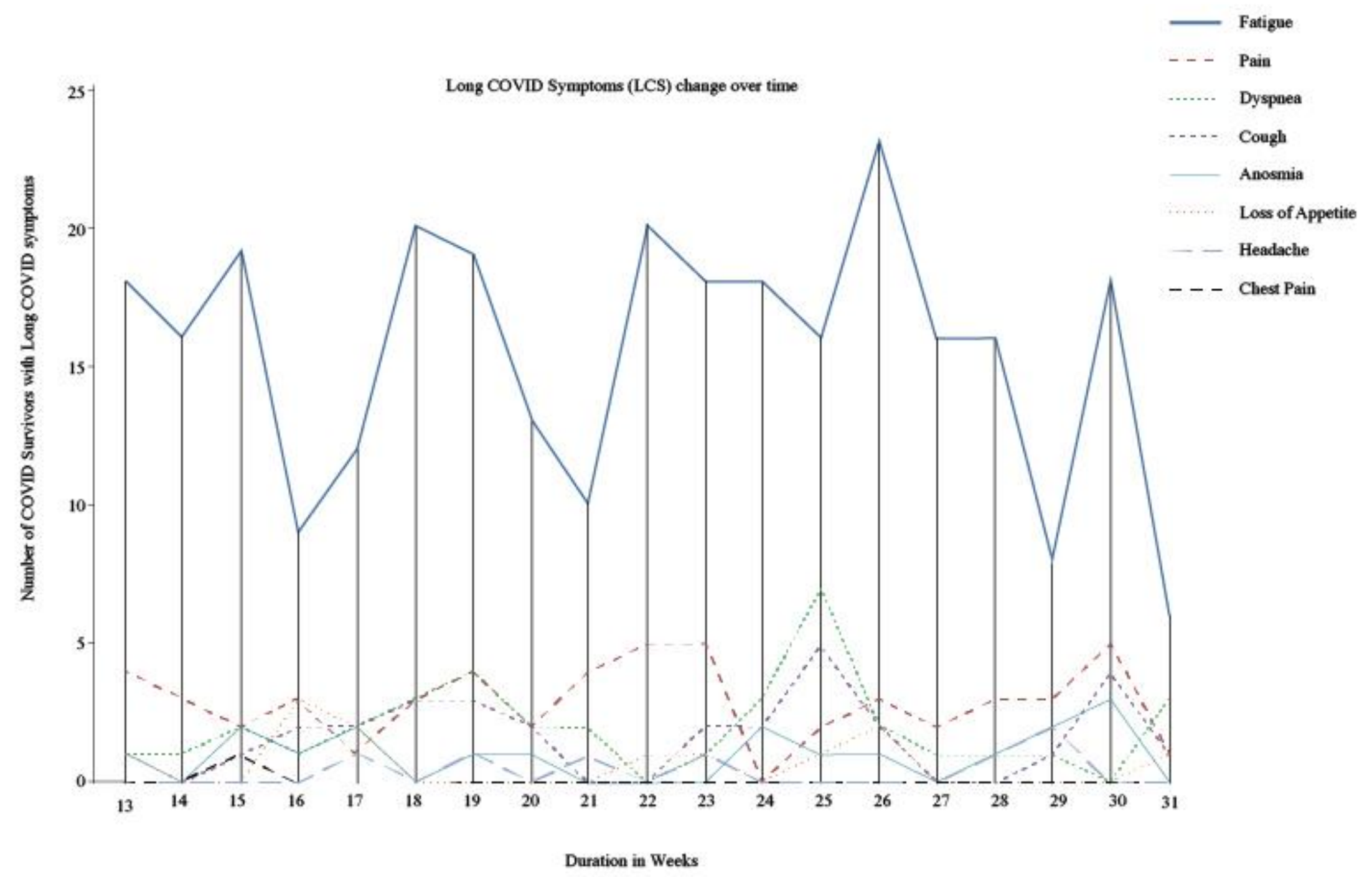


medRxiv preprint doi: https://doi.org/10.1101/2021.07.03.21259626; this version posted July 6, 2021. The copyright holder for this preprint (which was not certified by peer review) is the author/funder, who has granted medRxiv a license to display the preprint in perpetuity. It is made available under a CC-BY-NC 4.0 International license.

\section{COVID related Information}

According to WHO working group classification ${ }^{24}, 63.2 \%$ (1390) of the ACS had mild COVID, $23.7 \%$ (520) had moderate COVID and .4\% (8) had severe COVID-19. The ratio of the severity in ACS, PACS and LCS were mostly similar (Table 1).93.9\% (2063) respondents opted to follow the advice of the government telemedicine team by resting at home, undertaking isolation and using advised medication. 5.7\% (126) needed supplementary oxygen either at home or hospital, .2\% (5) were admitted to hospital and required noninvasive ventilation and $.2 \%$ (4) were admitted to a dedicated COVID Intensive Care Unit (ICU) with or without mechanical ventilation. Further detail of the COVID related information of ACS, PACS and LCS are appended in Table 1.

\section{Cardio-respiratory Function}

The mean resting heart rate for participants with PACS and LCS was $82.5 \pm 6.9$, and $82.4 \pm 6.7$ beats per minute; systolic blood pressure was $115.8 \pm 8.9,115.4 \pm 8.7 \mathrm{~mm} / \mathrm{Hg}$; diastolic blood

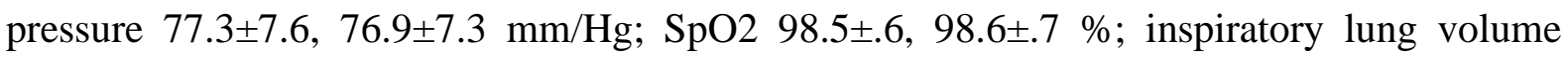
$1155 \pm 62,1154 \pm 61 \mathrm{~mL} / \mathrm{min}$; expiratory lung volume $872 \pm 54,871 \pm 56 \mathrm{ml} / \mathrm{min}$; and Vo2Max $33.0 \pm 3.4,33.1 \pm 3.3$ respectively. However, figure 5 shows, no notable changes of mean in LCS compared to all COVID survivors. 
medRxiv preprint doi: https://doi.org/10.1101/2021.07.03.21259626; this version posted July 6,2021 . The copyright holder for this preprint (which was not certified by peer review) is the author/funder, who has granted medRxiv a license to display the preprint in perpetuity. It is made available under a CC-BY-NC 4.0 International license .

Figure 5: Comparison of Cardio-respiratory system variables between COVID-19 survivors and people with Long COVID symptoms (LCS)

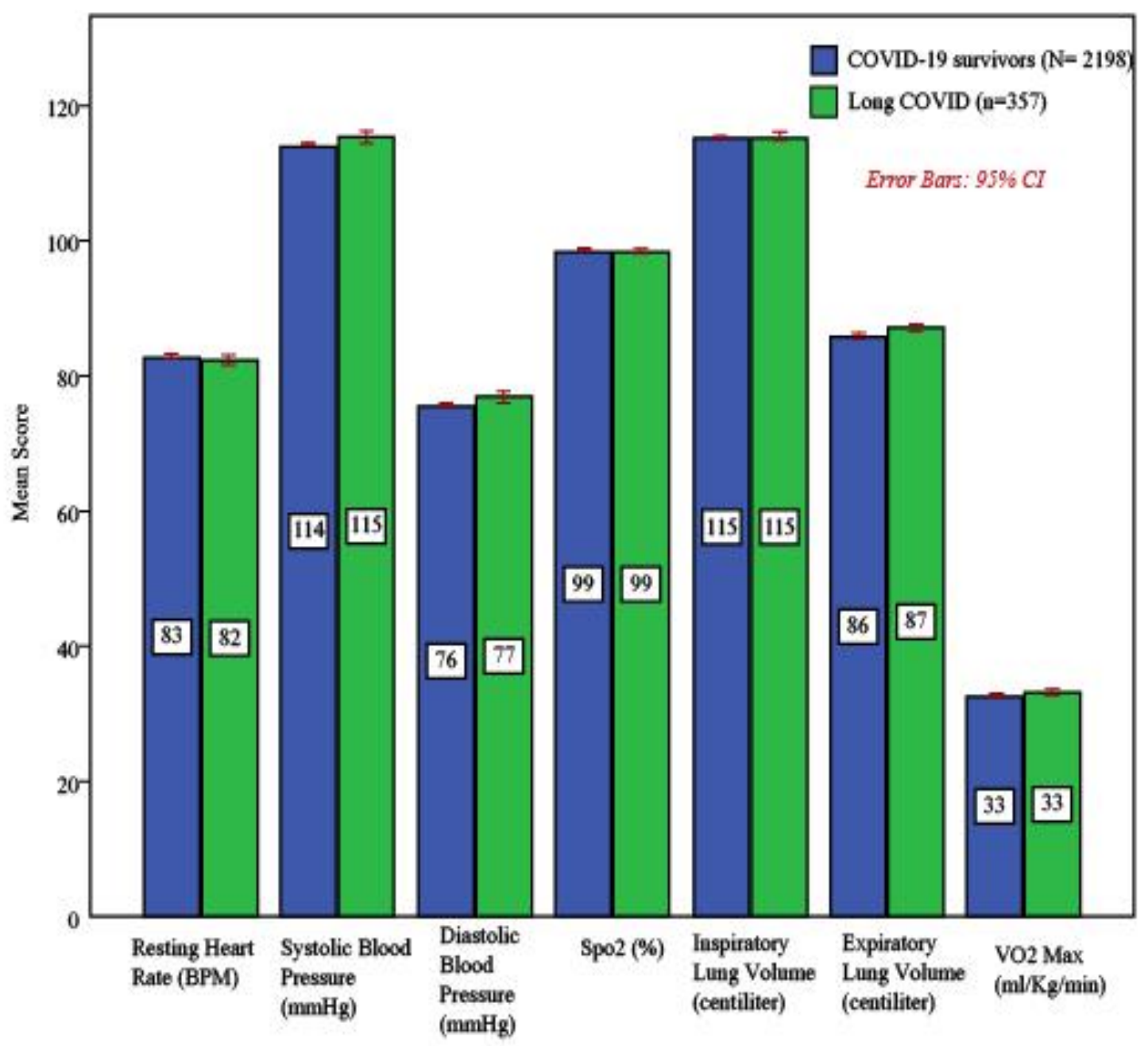


medRxiv preprint doi: https://doi.org/10.1101/2021.07.03.21259626; this version posted July 6 , 2021. The copyright holder for this preprint (which was not certified by peer review) is the author/funder, who has granted medRxiv a license to display the preprint in perpetuity. It is made available under a CC-BY-NC 4.0 International license .

Post-COVID functional status (PCFS)

$88.2 \%$ (1939) of ACS had no residual functional limitation and74.9\% (371) of PACS and $73.3 \%$ (261) of LCS also had no residual functional limitations. However, 20.2\% (100) of PACS and 20.2\% (72) of LCS reported negligible functional limitation and $4.8 \%$ (24) of PACS and 6.5\% (23) of LCS reported slight functional limitations. Overall, the mean PCFS in PACS was $12.41 \pm 8.7$ and in LCS was $12.14 \pm 8.8$ in 0 to 100 scores. Compared to ACS, participants with LCS had higher mean scores in relation to progression of weeks (Figure 6), indicating that functional limitation is more progressive with time in LCS survivors compared to others. 
medRxiv preprint doi: https://doi.org/10.1101/2021.07.03.21259626; this version posted July 6,2021 . The copyright holder for this preprint (which was not certified by peer review) is the author/funder, who has granted medRxiv a license to display the preprint in perpetuity. It is made available under a CC-BY-NC 4.0 International license .

Figure 6: Comparison of Post-COVID Functional Status Scale between COVID-19 survivors and people with Long COVID symptoms (LCS) according to duration since COVID positive

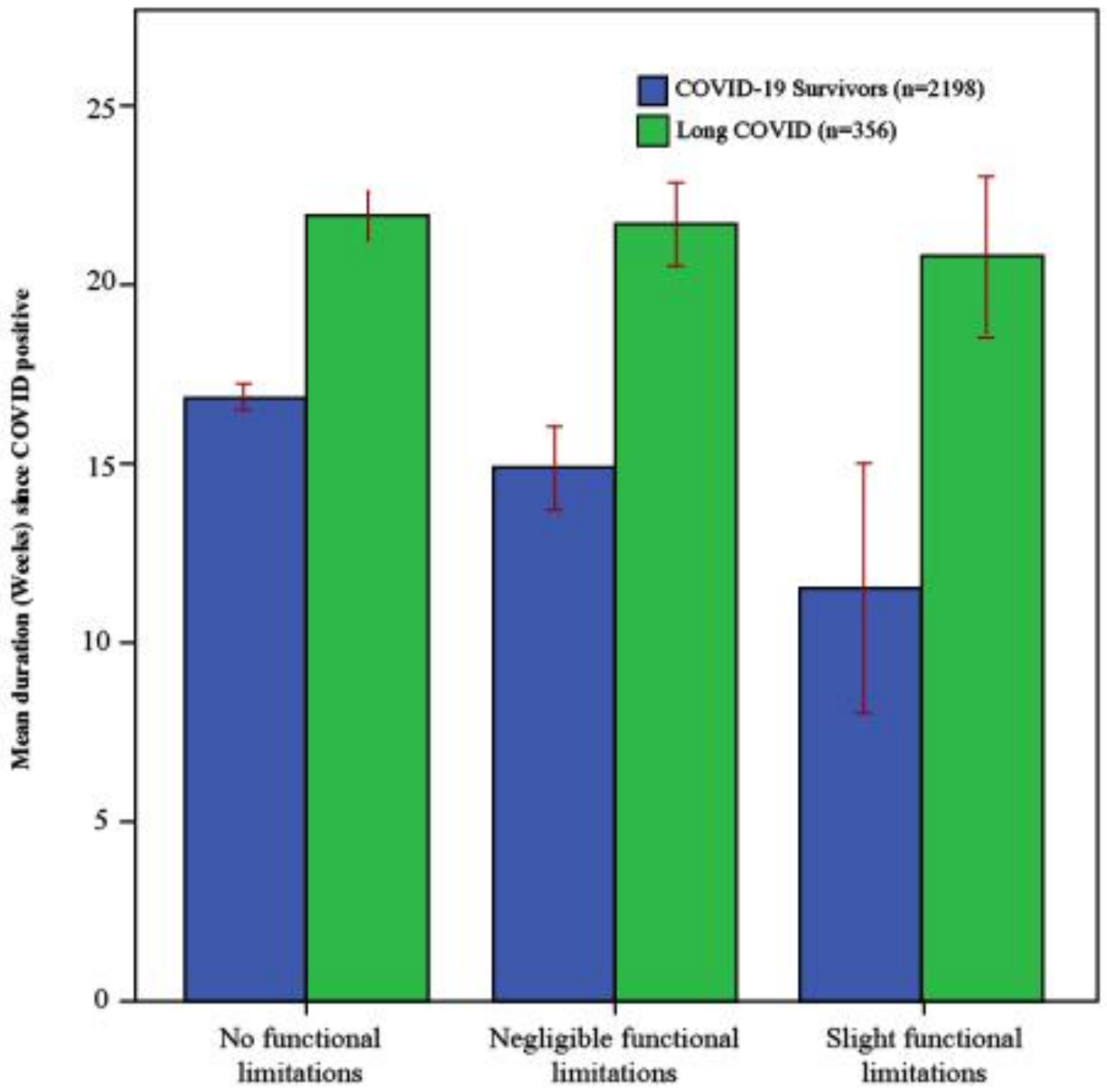

Post-COVID Functional Status 
medRxiv preprint doi: https://doi.org/10.1101/2021.07.03.21259626; this version posted July 6, 2021. The copyright holder for this preprint (which was not certified by peer review) is the author/funder, who has granted medRxiv a license to display the preprint in perpetuity. It is made available under a CC-BY-NC 4.0 International license.

\section{Relationship of LCS with Socio-demographics}

Table 2 represents a segregated relationship of socio-demographic and health related factors with LCS in correlation model. Categorical age was associated with LCS $(p<.05)$, whereas pain was associated separately with overall age of the population $(\mathrm{p}<.05)$. LCS were associated with gender $(\mathrm{p}<.01)$, marital status $(\mathrm{p}<.05)$, area of residence $(\mathrm{p}<.01)$, occupation $(\mathrm{p}<.001)$ and severity of COVID-19 ( $\mathrm{p}<.001)$.

\section{Factors associated with LCS}

Table 3 describes the binary logistic regression model to determine the factors associated with LCS. People living in rural areas had a relationship with LCS $(\beta .41, \mathrm{p}<.01$. Other relationships included being a housewife and private employees $(\beta .48, \mathrm{p}<.001$, ), frontline worker (police and health professionals) $(\beta .12, \mathrm{p}<.001$,$) , people with co-morbidities (\beta .365$, $\mathrm{p}<.01)$, and smokers $(\beta .50, \mathrm{p}<.01)$.The PCFS was also found to be positively associated $(\beta .14$, $\mathrm{p}<.001)$.However, male gender had a reverse relationship with LCS $(\beta-.36, \mathrm{p}<.01)$, and the presence of a Rhesus positive factor in the blood group also had similar reverse relationship $(\beta-.596, \mathrm{p}<.05)$.

\section{Factors associated with limited function in LCS people}

Table 4 shows the factors associated with limited functional scores in participants with LCS in a multiple linear regression model. The female gender was related with functional limitation $(\beta .064, \mathrm{p}<.05)$. Other linear associations were fatigue $(\beta .094, \mathrm{p}<.001)$, pain $(\beta .17$, $\mathrm{p}<.001)$, systolic blood pressure $(\beta .71, \mathrm{p}<.01)$, diastolic blood pressure $(\beta .75, \mathrm{p}<.01)$, inspiratory lung volume $(\beta .27, \mathrm{p}<.01)$, expiratory lung volume $(\beta .69, \mathrm{p}<.01)$ and Vo2Max $(\beta .213, \mathrm{p}<.01)$.A reverse relationship was found with males $(\mathrm{p}<.05)$, people aged below 50 years $(\mathrm{p}<.001)$ and people who had mild COVID-19 $(\mathrm{p}<.001)$.

\section{Prediction of $L C S$}

Figure 7 predicts the presence of LCS and longer duration of LCS through the SEM. Goodness of fit indicates a satisfactory level of 'good fit' of assumptions for external validity ( $\chi 2$ 1302.88, df 29, p .001, $\chi 2 / \mathrm{df} 44.92$, Root mean square error of approximation (RMSEA).166 [90\% CI .158, .174], Root mean square residual (RMR) 1.449, CFI .147, GFI .882). Presence of LCS was positively associated $\left(R^{2} .098\right)$ with frontline workers (police and health professionals) $(\beta .15, \mathrm{p}<.01)$, limited function $(\beta .10, \mathrm{p}<.001)$, being female $(\beta .07$, $\mathrm{p}<.001)$ smokers $(\beta .07, \mathrm{p}<.001)$, and the severity of COVID-19 $(\beta .02, \mathrm{p}<.001)$.A longer 
medRxiv preprint doi: https://doi.org/10.1101/2021.07.03.21259626; this version posted July 6,2021 . The copyright holder for this preprint (which was not certified by peer review) is the author/funder, who has granted medRxiv a license to display the preprint in perpetuity. It is made available under a CC-BY-NC 4.0 International license.

duration of LCS was positively associated $\left(R^{2} .041\right)$ with being female $(\beta .12, \mathrm{p}<.001)$, limited function $(\beta .09, \mathrm{p}<.001), \operatorname{smokers}(\beta .08, \mathrm{p}<.01)$, and people living in rural areas $(\beta .06, \mathrm{p}<.05)$. Interestingly, age has a reverse relationship with a longer duration of $\operatorname{LCS}(\beta-.05, \mathrm{p}<.05)$.

Figure 7: Structural equation model (SEM) for predictors of Long COVID Symptoms

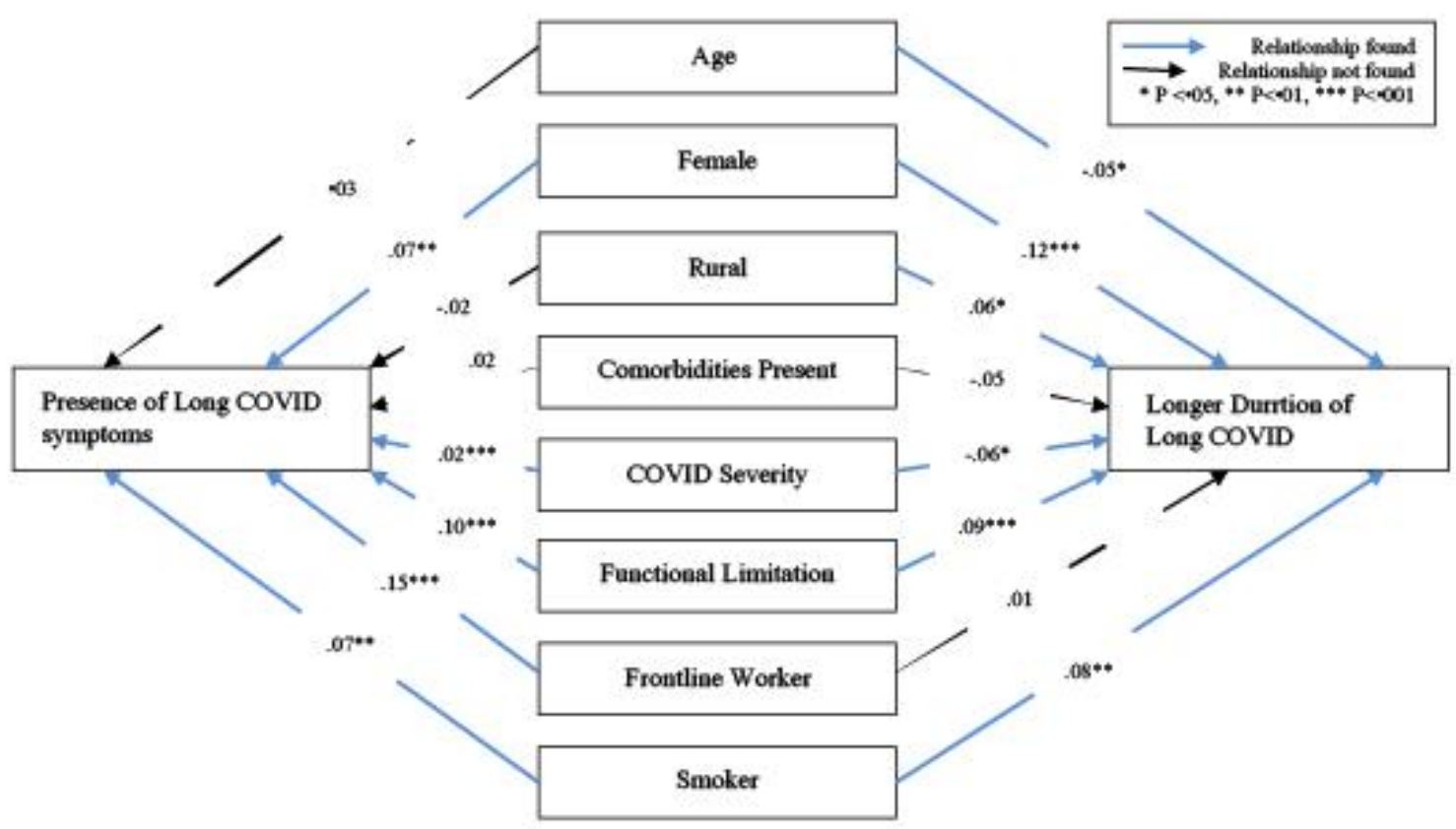


medRxiv preprint doi: https://doi.org/10.1101/2021.07.03.21259626; this version posted July 6,2021 . The copyright holder for this preprint (which was not certified by peer review) is the author/funder, who has granted medRxiv a license to display the preprint in perpetuity.

It is made available under a CC-BY-NC 4.0 International license .

Table 1: Baseline characteristics for Inception Cohort of COVID-19 positive cases

\begin{tabular}{|c|c|c|c|c|}
\hline Variables & Categories & $\begin{array}{c}\text { Acute COVID-19 } \\
\text { symptoms (ACS) } \\
(\mathrm{N}=2198)\end{array}$ & $\begin{array}{c}\text { Post-acute } \\
\text { COVID-19 } \\
\text { symptoms (PACS) } \\
(\mathrm{N}=495)\end{array}$ & $\begin{array}{c}\text { Long COVID } \\
\text { symptoms (LCS) } \\
(\mathrm{N}=356)\end{array}$ \\
\hline \multicolumn{5}{|c|}{ Socio-demographic variables } \\
\hline Age (Years) & Overall & $38 \cdot 7 \pm 11 \cdot 4$ & $38 \cdot 86 \pm 11 \cdot 3$ & $38 \cdot 42 \pm 11 \cdot 3$ \\
\hline \multirow{6}{*}{$\begin{array}{l}\text { Age (years) in } \\
\text { Categories }\end{array}$} & $18-30$ & $669(30 \cdot 4 \%)$ & $125(25 \cdot 3 \%)$ & $94(26 \cdot 4 \%)$ \\
\hline & $31-40$ & $718(32 \cdot 7 \%)$ & $181(36 \cdot 6 \%)$ & $131(36 \cdot 8 \%)$ \\
\hline & $41-50$ & $473(21 \cdot 5 \%)$ & $102(20 \cdot 6 \%)$ & $70(19 \cdot 7 \%)$ \\
\hline & $51-60$ & $277(12 \cdot 6 \%)$ & $74(14.9 \%)$ & $55(15 \cdot 4 \%)$ \\
\hline & $61-70$ & $47(2 \cdot 1 \%)$ & $10(2 \cdot 0 \%)$ & $3(\cdot 8 \%)$ \\
\hline & $>70$ & $14(\cdot 6 \%)$ & $3(0 \cdot 6 \%)$ & $3(\cdot 8 \%)$ \\
\hline \multirow[t]{2}{*}{ Sex } & Male & $1591(72 \cdot 4 \%)$ & $342(69 \cdot 1 \%)$ & $242(68 \%)$ \\
\hline & Female & $607(27 \cdot 6)$ & $153(30 \cdot 9 \%)$ & $114(32 \%)$ \\
\hline \multirow[t]{3}{*}{ Marital status } & Married & $1868(85 \%)$ & $424(85 \cdot 7 \%)$ & $304(85 \cdot 4 \%)$ \\
\hline & Unmarried & $308(14 \%)$ & $61(12 \cdot 3 \%)$ & $45(12 \cdot 6 \%)$ \\
\hline & Widow/ widower & $22(1 \%)$ & $10(2 \cdot 0 \%)$ & $7(2 \cdot 0 \%)$ \\
\hline \multirow[t]{5}{*}{ Education } & No formal Education & $36(1.6 \%)$ & $6(1 \cdot 2 \%)$ & $1(\cdot 3 \%)$ \\
\hline & Primary Education & $57(2 \cdot 6 \%)$ & $8(1 \cdot 6 \%)$ & $6(1.7 \%)$ \\
\hline & Secondary Education & $265(12 \cdot 1 \%)$ & $68(13 \cdot 7 \%)$ & $52(14 \cdot 6 \%)$ \\
\hline & Higher secondary & $739(33 \cdot 6 \%)$ & $148(29.9 \%)$ & $110(30 \cdot 9 \%)$ \\
\hline & $\begin{array}{l}\text { Bachelor degree and } \\
\text { above }\end{array}$ & $1101(50 \cdot 1 \%)$ & $265(53 \cdot 5 \%)$ & $187(52 \cdot 5 \%)$ \\
\hline \multirow[t]{2}{*}{ Residing area } & Rural & $1652(75 \cdot 2 \%)$ & $355(71 \cdot 7 \%)$ & $254(71 \cdot 3 \%)$ \\
\hline & Urban & $546(24 \cdot 8 \%)$ & $140(28 \cdot 3 \%)$ & $102(28 \cdot 7 \%)$ \\
\hline \multirow[t]{6}{*}{ Occupation } & Private jobs & $1212(55 \cdot 1 \%)$ & $252(50 \cdot 9 \%)$ & $179(50 \cdot 3 \%)$ \\
\hline & Government jobs & $298(13 \cdot 6 \%)$ & $61(12 \cdot 3 \%)$ & $40(11 \cdot 2 \%)$ \\
\hline & Housewife & $229(10 \cdot 4 \%)$ & $44(8 \cdot 9 \%)$ & $28(7 \cdot 9 \%)$ \\
\hline & Students & $225(10 \cdot 2 \%)$ & $47(9 \cdot 5 \%)$ & $37(10 \cdot 4 \%)$ \\
\hline & $\begin{array}{l}\text { Health care } \\
\text { professionals }\end{array}$ & $133(6 \cdot 1 \%)$ & $48(9 \cdot 7 \%)$ & $36(10 \cdot 1 \%)$ \\
\hline & $\begin{array}{l}\text { Law enforcement } \\
\text { agency }\end{array}$ & $101(4 \cdot 6 \%)$ & $43(8 \cdot 7 \%)$ & $36(10 \cdot 1 \%)$ \\
\hline \multicolumn{3}{|c|}{ Health Indicators } & & \\
\hline
\end{tabular}


medRxiv preprint doi: https://doi.org/10.1101/2021.07.03.21259626; this version posted July 6, 2021. The copyright holder for this preprint (which was not certified by peer review) is the author/funder, who has granted medRxiv a license to display the preprint in perpetuity. It is made available under a CC-BY-NC 4.0 International license.

\begin{tabular}{|c|c|c|c|c|}
\hline \multirow{5}{*}{$\begin{array}{l}\text { Major } \\
\text { Comorbidities } \\
\text { (multiple } \\
\text { responses) }\end{array}$} & Hypertension & $271(25 \cdot 6 \%)$ & $88(24 \cdot 9 \%)$ & $63(26 \cdot 4 \%)$ \\
\hline & Diabetes & $240(22 \cdot 7 \%)$ & $69(19 \cdot 5 \%)$ & $54(22 \cdot 6 \%)$ \\
\hline & Lung Disease & $73(6 \cdot 9 \%)$ & $28(7 \cdot 9 \%)$ & $24(10 \cdot 0 \%)$ \\
\hline & Heart Disease & $63(6 \%)$ & $18(5 \cdot 1 \%)$ & $13(5 \cdot 4 \%)$ \\
\hline & Kidney Disease & $18(1 \cdot 7 \%)$ & $5(1.4 \%)$ & $1(\cdot 4 \%)$ \\
\hline \multirow[t]{9}{*}{ Blood Group } & B Positive & $763(34 \cdot 7 \%)$ & $167(33 \cdot 7 \%)$ & $129(36 \cdot 2 \%)$ \\
\hline & A Positive & $508(23 \cdot 1 \%)$ & $111(22 \cdot 4 \%)$ & $68(19 \cdot 1 \%)$ \\
\hline & O Positive & $514(23 \cdot 4 \%)$ & $130(26 \cdot 3 \%)$ & $93(26 \cdot 1 \%)$ \\
\hline & AB Positive & $230(10 \cdot 5 \%)$ & $56(11 \cdot 3 \%)$ & $46(12.9 \%)$ \\
\hline & O Negative & $24(1 \cdot 1 \%)$ & $6(1 \cdot 2 \%)$ & $3(\cdot 8 \%)$ \\
\hline & B Negative & $32(1.5 \%)$ & $6(1 \cdot 2 \%)$ & $6(1.7 \%)$ \\
\hline & A Negative & $36(1.6 \%)$ & $8(1 \cdot 6 \%)$ & $6(1.7 \%)$ \\
\hline & AB Negative & $13(.6 \%)$ & 0 & 0 \\
\hline & Don't Know & $78(3 \cdot 5 \%)$ & $11(2 \cdot 2 \%)$ & $5(1 \cdot 4 \%)$ \\
\hline \multicolumn{5}{|c|}{ COVID-related information } \\
\hline \multirow{3}{*}{$\begin{array}{l}\text { WHO Severity } \\
\text { of COVID index }\end{array}$} & Mild COVID & $1670(75 \cdot 9 \%)$ & $305(61 \cdot 6 \%)$ & $217(61 \%)$ \\
\hline & Moderate COVID & $520(23 \cdot 6 \%)$ & $186(37 \cdot 6 \%)$ & $135(37.9 \%)$ \\
\hline & Severe COVID & $8(\cdot 4 \%)$ & $4(\cdot 8 \%)$ & $4(1 \cdot 1 \%)$ \\
\hline \multirow{4}{*}{$\begin{array}{l}\text { Treatment } \\
\text { Received }\end{array}$} & Usual Care* & $2063(93 \cdot 9 \%)$ & $434(87 \cdot 7 \%)$ & $307(86 \cdot 2 \%)$ \\
\hline & Oxygen supplement & $126(5 \cdot 7 \%)$ & $57(11 \cdot 5 \%)$ & $45(12 \cdot 6 \%)$ \\
\hline & Ventilation** & $5(\cdot 2 \%)$ & $3(\cdot 6 \%)$ & $3(\cdot 8 \%)$ \\
\hline & $\mathrm{ICU} * * *$ & $4(\cdot 2 \%)$ & $1(\cdot 2 \%)$ & $1(\cdot 3 \%)$ \\
\hline \multirow{4}{*}{$\begin{array}{l}\text { Post COVID-19 } \\
\text { Functional } \\
\text { Status Scale } \\
\text { (PCFS) }\end{array}$} & Overall Mean, SD & $10 \cdot 18 \pm 8 \cdot 3$ & $12 \cdot 41 \pm 8 \cdot 7$ & $12 \cdot 14 \pm 8 \cdot 8$ \\
\hline & $\begin{array}{l}\text { No Functional } \\
\text { Limitation }\end{array}$ & $1939(88 \cdot 2 \%)$ & $371(74.9 \%)$ & $261(73 \cdot 3 \%)$ \\
\hline & Negligible Limitation & $221(10 \cdot 1 \%)$ & $100(20 \cdot 2 \%)$ & $72(20 \cdot 2 \%)$ \\
\hline & Slight Limitation & $38(1 \cdot 7)$ & $24(4 \cdot 8 \%)$ & $23(6 \cdot 5 \%)$ \\
\hline
\end{tabular}

* Usual care $=$ isolation, medication and care at home as per the advice of government telemedicine team

** Ventilation= non-invasive ventilation assistance at Hospital

*** ICU $=$ admitted in dedicated COVID ICU with or without mechanical ventilation and received critical care 
Table 2: Relationship among socio-demographic variables and Long COVID symptoms of the COVID-19 survivors

\begin{tabular}{|c|c|c|c|c|c|c|c|c|c|c|}
\hline Variable & Descriptive & $\begin{array}{l}\text { Long } \\
\text { COVID } \\
\text { (overall) }\end{array}$ & Fatigue & Pain & Dyspnea & Cough & Anosmia & $\begin{array}{l}\text { Lack of } \\
\text { appetite }\end{array}$ & Headache & $\begin{array}{l}\text { Chest } \\
\text { Pain }\end{array}$ \\
\hline \multirow[t]{2}{*}{$\begin{array}{l}\text { Age } \\
\text { (overall) }\end{array}$} & Mean, SD & $38 \cdot 4 \pm 11 \cdot 3$ & $38 \cdot 1 \pm 11 \cdot 3$ & $40 \cdot 9 \pm 10 \cdot 1$ & $38 \cdot 6 \pm 9 \cdot 2$ & $38 \cdot 0 \pm 13 \cdot 8$ & $\begin{array}{l}36 \cdot 6 \pm 14 \cdot \\
1\end{array}$ & $37 \cdot 8 \pm 8 \cdot 6$ & $37 \cdot 3 \pm 7 \cdot 8$ & 55 \\
\hline & Independent $\mathrm{t}(\mathrm{p})$ & $.895(\cdot 371)$ & $.938(\cdot 349)$ & $-1.9(\cdot 05) *$ & $-\cdot 115(\cdot 908)$ & $\cdot 182(\cdot 856)$ & $\begin{array}{l}\cdot 674(\cdot 50 \\
1)\end{array}$ & $\cdot 182(\cdot 856)$ & $\cdot 264(\cdot 792)$ & $\begin{array}{l}\text { - } \\
1 \cdot 47(\cdot 14 \\
2)\end{array}$ \\
\hline \multirow{7}{*}{$\begin{array}{l}\text { Age } \\
\text { category }\end{array}$} & 18-30 years & $94(26 \cdot 4)$ & $83(23 \cdot 3)$ & $10(2 \cdot 8)$ & $6(1 \cdot 7)$ & $9(2 \cdot 5)$ & $6(1 \cdot 7)$ & $2(0 \cdot 60)$ & $2(0 \cdot 60)$ & 0 \\
\hline & $31-40$ years & $131(36 \cdot 7)$ & $103(28 \cdot 9)$ & $21(5 \cdot 9)$ & $17(4 \cdot 8)$ & $13(3 \cdot 7)$ & $8(2 \cdot 2)$ & $6(1 \cdot 7)$ & $4(1 \cdot 1)$ & 0 \\
\hline & $41-50$ years & $70(19 \cdot 6)$ & $61(17 \cdot 1)$ & $17(4 \cdot 8)$ & $9(2 \cdot 5)$ & $3(0 \cdot 80)$ & 0 & $3(0 \cdot 80)$ & $2(0 \cdot 60)$ & 0 \\
\hline & 51-60 years & $55(15 \cdot 4)$ & $43(12 \cdot 1)$ & $12(3 \cdot 4)$ & $5(1 \cdot 4)$ & $4(1 \cdot 1)$ & $3(0 \cdot 80)$ & $1(0 \cdot 30)$ & 0 & $1(0 \cdot 30)$ \\
\hline & $61-70$ years & $3(\cdot 8)$ & $2(\cdot 60)$ & 0 & 0 & $1(0 \cdot 30)$ & 0 & 0 & 0 & 0 \\
\hline & $>70$ years & $3(\cdot 8)$ & $3(0 \cdot 80)$ & 0 & 0 & $1(0 \cdot 30)$ & $1(0 \cdot 30)$ & 0 & 0 & 0 \\
\hline & $\chi^{2(p)}$ & $\begin{array}{l}11 \cdot 4(\cdot 043) \\
*\end{array}$ & $5 \cdot 59(\cdot 347)$ & $7 \cdot 59(\cdot 180)$ & $3 \cdot 81(\cdot 576)$ & $6 \cdot 77(\cdot 238)$ & $\begin{array}{l}9 \cdot 54(\cdot 08 \\
9)\end{array}$ & $1 \cdot 83(\cdot 872)$ & $1 \cdot 91(\cdot 861)$ & $\begin{array}{l}5 \cdot 48(\cdot 35 \\
9)\end{array}$ \\
\hline \multirow[t]{3}{*}{ Gender } & Male & $242(68 \cdot 0)$ & $199(55 \cdot 9)$ & $37(10 \cdot 4)$ & $26(7 \cdot 3)$ & $25(7 \cdot 0)$ & $11(3 \cdot 1)$ & $8(2 \cdot 2)$ & $4(1 \cdot 1)$ & $1(0 \cdot 30)$ \\
\hline & Female & $114(32 \cdot 0)$ & $96(27 \cdot 0)$ & $23(6 \cdot 5)$ & $11(3 \cdot 1)$ & $6(1 \cdot 7)$ & $7(2 \cdot 0)$ & $4(1 \cdot 1)$ & $4(1 \cdot 1)$ & 0 \\
\hline & $\chi^{2}(\mathrm{p})$ & $\begin{array}{l}7 \cdot 74(\cdot 005) \\
* *\end{array}$ & $\cdot 214(\cdot 644)$ & $1 \cdot 32(\cdot 251)$ & $\cdot 100(\cdot 752)$ & $2 \cdot 50(\cdot 114)$ & $\begin{array}{l}.411(\cdot 52 \\
2)\end{array}$ & $.010(\cdot 921)$ & $1 \cdot 21(\cdot 270)$ & $\begin{array}{l}.472(\cdot 49 \\
2)\end{array}$ \\
\hline Marital & Married & $304(85 \cdot 4)$ & $248(69 \cdot 7)$ & $53(14.9)$ & $33(9 \cdot 3)$ & $26(7 \cdot 3)$ & $15(4 \cdot 2)$ & $12(3 \cdot 4)$ & $8(2 \cdot 2)$ & $1(0 \cdot 30)$ \\
\hline
\end{tabular}




\begin{tabular}{|c|c|c|c|c|c|c|c|c|c|c|}
\hline \multirow[t]{3}{*}{ status } & Unmarried & $45(12 \cdot 6)$ & $40(11 \cdot 2)$ & $4(1 \cdot 1)$ & $2(\cdot 60)$ & $5(1 \cdot 4)$ & $3(\cdot 80)$ & 0 & $1(0 \cdot 20)$ & 0 \\
\hline & Widow/ widower & $7(2 \cdot 0)$ & $7(2 \cdot 0)$ & $3(0 \cdot 0)$ & $2(\cdot 60)$ & 0 & 0 & 0 & 0 & 0 \\
\hline & $\chi^{2}(\mathrm{p})$ & $7 \cdot 81(\cdot 02) *$ & $2 \cdot 95(\cdot 229)$ & $5 \cdot 48(\cdot 06)$ & $4 \cdot 26(\cdot 119)$ & $1 \cdot 00(\cdot 605)$ & $\begin{array}{l}\cdot 625(\cdot 73 \\
1)\end{array}$ & $2 \cdot 12(\cdot 346)$ & $1 \cdot 40(\cdot 497)$ & $\begin{array}{l}.172(\cdot 91 \\
8)\end{array}$ \\
\hline \multirow[t]{6}{*}{ Education } & $\begin{array}{l}\text { No formal } \\
\text { Education }\end{array}$ & $1(0 \cdot 3)$ & $1(0 \cdot 3)$ & 0 & 0 & 0 & 0 & 0 & 0 & 0 \\
\hline & Primary Education & $6(1 \cdot 7)$ & $6(1 \cdot 7)$ & $1(0 \cdot 30)$ & 0 & 0 & 0 & 0 & 0 & 0 \\
\hline & $\begin{array}{l}\text { Secondary } \\
\text { Education }\end{array}$ & $52(14 \cdot 6)$ & $42(11 \cdot 8)$ & $9(2 \cdot 5)$ & $3(0 \cdot 8)$ & $5(1 \cdot 4)$ & $3(0 \cdot 80)$ & 0 & 0 & 0 \\
\hline & Higher secondary & $110(30 \cdot 9)$ & $88(24 \cdot 7)$ & $20(5 \cdot 6)$ & $9(2 \cdot 5)$ & $11(3 \cdot 1)$ & $7(2 \cdot 0)$ & $6(1 \cdot 7)$ & $2(0 \cdot 60)$ & 0 \\
\hline & Bachelor or Above & $187(52 \cdot 5)$ & $158(44 \cdot 4)$ & $30(8 \cdot 4)$ & $25(7 \cdot 0)$ & $15(4 \cdot 2)$ & $8(2 \cdot 2)$ & $6(1 \cdot 7)$ & $6(1 \cdot 7)$ & $1(0 \cdot 30)$ \\
\hline & $\chi^{2}(\mathrm{p})$ & $7 \cdot 94(\cdot 09)$ & $2.59(.628)$ & $.437(.979)$ & $4 \cdot 36(\cdot 359)$ & $1.06(0 \cdot 90)$ & $\begin{array}{l}1 \cdot 05(0 \cdot 9 \\
0)\end{array}$ & $\begin{array}{l}3 \cdot 54 \\
(0 \cdot 472)\end{array}$ & $2 \cdot 23(\cdot 693)$ & $\begin{array}{l}.906(\cdot 92 \\
4)\end{array}$ \\
\hline \multirow{3}{*}{$\begin{array}{l}\text { Residing } \\
\text { area }\end{array}$} & Rural & $254(71 \cdot 3)$ & $207(58 \cdot 1)$ & $48(13 \cdot 5)$ & $31(8 \cdot 7)$ & $24(6 \cdot 7)$ & $14(3 \cdot 9)$ & $10(2 \cdot 8)$ & $6(1 \cdot 7)$ & 0 \\
\hline & Urban & $102(28 \cdot 7)$ & $88(24 \cdot 7)$ & $12(3 \cdot 4)$ & $6(1 \cdot 7)$ & $7(2 \cdot 0)$ & $4(1 \cdot 1)$ & $2(0 \cdot 60)$ & $2(0 \cdot 60)$ & $1(0 \cdot 30)$ \\
\hline & $\chi^{2}(\mathrm{p})$ & $\begin{array}{l}9 \cdot 35(\cdot 002) \\
* *\end{array}$ & $1 \cdot 17(\cdot 279)$ & $2 \cdot 64(\cdot 104)$ & $3 \cdot 12(\cdot 07)$ & $.612(\cdot 434)$ & $\begin{array}{l}\cdot 383(\cdot 53 \\
6)\end{array}$ & $\cdot 873(\cdot 350)$ & $.053(\cdot 817)$ & $\begin{array}{l}2 \cdot 49(\cdot 11 \\
4)\end{array}$ \\
\hline \multirow[t]{5}{*}{ Occupation } & Students & $37(10 \cdot 4)$ & $32(9 \cdot 0)$ & $4(1 \cdot 1)$ & $2(0 \cdot 60)$ & $5(1 \cdot 4)$ & $3(0 \cdot 80)$ & 0 & 0 & 0 \\
\hline & $\begin{array}{l}\text { Health care } \\
\text { profession }\end{array}$ & $36(10 \cdot 1)$ & $29(8 \cdot 1)$ & $11(3 \cdot 1)$ & $6(1 \cdot 7)$ & $3(0 \cdot 80)$ & $2(0 \cdot 60)$ & $2(0 \cdot 60)$ & $2(0 \cdot 60)$ & 0 \\
\hline & Legal Force & $36(10 \cdot 1)$ & $29(8 \cdot 1)$ & $8(2 \cdot 2)$ & $8(2 \cdot 2)$ & $7(2 \cdot 0)$ & 0 & $3(0 \cdot 80)$ & $1(0 \cdot 30)$ & 0 \\
\hline & Housewife & $28(7 \cdot 9)$ & $25(7 \cdot 0)$ & $4(1 \cdot 1)$ & $1(0 \cdot 30)$ & 0 & $1(0 \cdot 30)$ & $1(0 \cdot 30)$ & 0 & 0 \\
\hline & Government jobs & $40(11 \cdot 2)$ & $33(9 \cdot 3)$ & $6(1 \cdot 7)$ & $4(1 \cdot 1)$ & $4(1 \cdot 1)$ & $3(\cdot 80)$ & 0 & $1(0 \cdot 30)$ & 0 \\
\hline
\end{tabular}




\begin{tabular}{|c|c|c|c|c|c|c|c|c|c|c|}
\hline & Private jobs & $179(50 \cdot 3)$ & $147(41 \cdot 3)$ & $27(7 \cdot 6)$ & $16(4 \cdot 5)$ & $12(3 \cdot 4)$ & $9(2 \cdot 5)$ & $6(1 \cdot 7)$ & $4(1 \cdot 1)$ & $1(0 \cdot 30)$ \\
\hline & $\chi^{2}(\mathrm{p})$ & $\begin{array}{l}58 \cdot 84(\cdot 0001 \\
) * * *\end{array}$ & $1 \cdot 49(\cdot 913)$ & $7 \cdot 15(\cdot 209)$ & $9 \cdot 37(\cdot 083)$ & $9 \cdot 96(\cdot 07)$ & $\begin{array}{l}3 \cdot 28(\cdot 65 \\
7)\end{array}$ & $5 \cdot 93(\cdot 312)$ & $3 \cdot 34(\cdot 647)$ & $\begin{array}{l}.992(.96 \\
3)\end{array}$ \\
\hline \multirow[t]{4}{*}{ Severity } & Mild Illness & $217(61 \cdot 0)$ & $182(51 \cdot 1)$ & $29(8 \cdot 1)$ & $1(0 \cdot 30)$ & $19(5 \cdot 3)$ & $9(2 \cdot 5)$ & $5(1 \cdot 4)$ & $7(2 \cdot 0)$ & 0 \\
\hline & Moderate Illness & $135(37 \cdot 9)$ & $110(30 \cdot 9)$ & $30(8 \cdot 4)$ & $34(9 \cdot 6)$ & $11(3 \cdot 1)$ & $9(2 \cdot 5)$ & $6(1 \cdot 7)$ & $1(0 \cdot 30)$ & $1(0 \cdot 30)$ \\
\hline & Severe Illness & $4(1 \cdot 1)$ & $3(0 \cdot 80)$ & $1(0 \cdot 30)$ & $2(0 \cdot 60)$ & $1(0 \cdot 30)$ & 0 & $1(0 \cdot 30)$ & 0 & 0 \\
\hline & $\chi^{2}(\mathrm{p})$ & $\begin{array}{l}104 \cdot 8 \\
(\cdot 0001) * * *\end{array}$ & $\cdot 511(\cdot 775)$ & $4 \cdot 85(\cdot 088)$ & $\begin{array}{l}\mathbf{6 1 \cdot 4 ( \cdot 0 0 0 1 )} \\
* * *\end{array}$ & $1 \cdot 38(\cdot 499)$ & $\begin{array}{l}1 \cdot 31(\cdot 51 \\
8)\end{array}$ & $\begin{array}{l}6 \cdot 98(0 \cdot 03) \\
*\end{array}$ & $2 \cdot 43(\cdot 296)$ & $\begin{array}{l}1 \cdot 64(\cdot 44 \\
0)\end{array}$ \\
\hline
\end{tabular}

Significant relationship values with a minimum of $5 \%$ margin of error are bolded and marked as $* \mathrm{p}<\cdot 05, * * \mathrm{p}<\cdot 01, * * * \mathrm{p}<\cdot 001$ 
Table 3: Factors associated with Long COVID symptoms

\begin{tabular}{|c|c|c|c|c|c|}
\hline \multirow[t]{2}{*}{ Independent Variables } & \multicolumn{5}{|c|}{ Presence of Long COVID Symptoms } \\
\hline & Nagelkerke $\mathrm{R}^{2}$ & $\beta$ & $\mathrm{P}$ & OR & $95 \% \mathrm{CI}$ \\
\hline Male gender & .007 & $-\cdot 364$ & $\cdot 006^{* * *}$ & .695 & $\cdot 537, \cdot 899$ \\
\hline Age 30 years and below & .003 & .237 & .079 & $1 \cdot 26$ & $.973,1.65$ \\
\hline Age 50 years and below & .002 & $\cdot 211$ & $\cdot 194$ & $1 \cdot 23$ & $.898,1.69$ \\
\hline Living in the Rural area & .009 & .416 & $\cdot 002^{* * *}$ & $1 \cdot 51$ & $1 \cdot 16,1 \cdot 98$ \\
\hline Having Mild COVID symptoms & .001 & $\cdot 105$ & $\cdot 397$ & $1 \cdot 11$ & $\cdot 872,1 \cdot 41$ \\
\hline Illiterate people & .004 & $1 \cdot 70$ & .096 & $5 \cdot 52$ & $.736,41 \cdot 3$ \\
\hline People with Higher secondary education or less degree & .002 & $\cdot 164$ & $\cdot 173$ & $1 \cdot 17$ & $.931,1.49$ \\
\hline Housewife and Private Jobholders & $\cdot 014$ & .485 & $\begin{array}{l}\cdot 0001 * * \\
*\end{array}$ & 1.62 & $1 \cdot 27,2 \cdot 07$ \\
\hline Students & .000 & $\cdot 000$ & .999 & $1 \cdot 0$ & $.68,1.47$ \\
\hline Frontline Workers (Health professionals and Police) & .045 & $\cdot 1 \cdot 23$ & $\begin{array}{l}\cdot 0001 * * \\
*\end{array}$ & $\cdot 290$ & $\cdot 206, \cdot 407$ \\
\hline Married people & .000 & .015 & .931 & $1 \cdot 01$ & $.727,1 \cdot 41$ \\
\hline People with Comorbidities & .007 & $\cdot 365$ & $\cdot 009 * *$ & 1.44 & $1 \cdot 09,1 \cdot 89$ \\
\hline Smoker & $\cdot 010$ & .509 & $\cdot 001 * *$ & .601 & $.445, \cdot 811$ \\
\hline Positive Rh factor in Blood Group & .006 & -.596 & $\cdot 017 *$ & $\cdot 551$ & $\cdot 338, \cdot 898$ \\
\hline Post COVID-19 Functional Status & $\cdot 061$ & $\cdot 14$ & $\begin{array}{l}\cdot 0001 * * \\
*\end{array}$ & $\cdot 319$ & $\cdot 137, \cdot 745$ \\
\hline
\end{tabular}


Table 4: Factors associated with limited function in people having Long COVID symptoms

\begin{tabular}{|c|c|c|c|c|}
\hline \multirow[t]{2}{*}{ Independent Variables } & \multicolumn{4}{|c|}{ Post COVID Functional Status Score } \\
\hline & $\mathrm{R}^{2}$ & $\beta$ & $\mathrm{p}$ & $95 \% \mathrm{CI}$ \\
\hline \multicolumn{5}{|l|}{ Socio-demographics } \\
\hline Female gender & .004 & .064 & $\cdot 010 *$ & $\cdot 194, \cdot 262$ \\
\hline Age 50 years and below & .003 & $-0 \cdot 051$ & $\cdot 0001 * * *$ & $\cdot 845, \cdot 900$ \\
\hline \multicolumn{5}{|l|}{ Long COVID Symptoms } \\
\hline Fatigue & .009 & .094 & $\cdot 0001 * * *$ & $\cdot 110, \cdot 170$ \\
\hline Pain & .031 & $\cdot 177$ & $\cdot 0001 * * *$ & $-.018, \cdot 011$ \\
\hline \multicolumn{5}{|l|}{ Cardio-respiratory Functions } \\
\hline $\mathrm{SpO} 2$ & $\cdot 001$ & $\cdot 012$ & $\cdot 822$ & $-.92,1.9$ \\
\hline Inspiratory Lung Volume & .073 & $\cdot 271$ & $\cdot 001 * *$ & $-2 \cdot 4, \cdot 73$ \\
\hline Expiratory Lung Volume & .485 & .696 & $\cdot 001 * *$ & $-1 \cdot 26,2 \cdot 26$ \\
\hline Vo2Max & .046 & $\cdot 213$ & $.001 * *$ & $-2 \cdot 15,2 \cdot 53$ \\
\hline
\end{tabular}

Significant relationship values with a minimum of $5 \%$ margin of error are bolded and marked as $* \mathrm{p}<\cdot 05, * * \mathrm{p}<\cdot 01, * * * \mathrm{p}<\cdot 001$ 
medRxiv preprint doi: https://doi.org/10.1101/2021.07.03.21259626; this version posted July 6, 2021. The copyright holder for this preprint (which was not certified by peer review) is the author/funder, who has granted medRxiv a license to display the preprint in perpetuity. It is made available under a CC-BY-NC 4.0 International license.

\section{Discussion}

In this study, the prevalence of LCS was $22.5 \%$ at 4 weeks and $16.1 \%$ at 12 weeks post diagnosis respectively. This is slightly higher than that reported by the UK study ${ }^{11}$ which reported the prevalence of PACS and LCS as $20 \%$ and $10 \%$ respectively. A recent study reported that the ongoing health issues of "fatigue or muscle weakness, sleep difficulties, and anxiety or depression." ${ }^{\prime \prime 6}$ were experienced within a cohort of 1733 survivors discharged from hospital in China, when followed up at a six-month time point. The limitation of that study was that all participants had been treated as In-patients in hospital, unlike this research study, in which the majority of participants did not receive hospital treatment and remained at home during recovery. Our study adds valuable research knowledge to the gap in understanding the prevalence and nature of LCS in survivors, who have remained at home during their illness. Our study is larger than the two previous studies conducted in Bangladesh ${ }^{13-14}$ and provides new research knowledge on associated risk factors for LCS, in addition to identifying risk factors associated with a longer time length of these symptoms.

In this study, the most common symptom during the acute phase was fever, closely followed by fatigue and upper respiratory tract symptoms. This is consistent with literature that has reported similar symptoms. ${ }^{25-26}$ The study found eight LCS, with fatigue being the most common symptom closely followed by muscle pain and dyspnea. In another study ${ }^{27}$, after three to nine months, $14 \%$ of individuals had fatigue problems. Most available literature unanimously reports fatigue ${ }^{1,15,16}$ as the most common LCS. After this, many studies reportbreathlessness ${ }^{28,1,6}$ as the second most common LCS with other studies citing anosmia, cough and myalgia to also be common. ${ }^{29}$ Augustin et $\mathrm{al}^{30}$, reported a study where nonhospitalized COVID-19 patients had more anosmia (12.4\%) and ageusia (11.1\%) than fatigue $(9.7 \%)$ and shortness of breath $(8.6 \%)$ over a four-to-seven-month recovery period.

This study reported that the majority of respondents had mild to moderate COVID-19 and approximately $93 \%$ decided to stay at home to recover without hospital treatment.62\% (308) of respondents with LCS reported mild disease, which would not require hospitalization. There is a paucity of literature in this area, which perhaps reflects the challenge of how to collect and gather data from people who do not perceive that they are sick enough to require hospital treatment and also considering that Bangladesh is an under-resourced country and the hospital system is private so usually hospital admission and treatment costs money. 
medRxiv preprint doi: https://doi.org/10.1101/2021.07.03.21259626; this version posted July 6, 2021. The copyright holder for this preprint (which was not certified by peer review) is the author/funder, who has granted medRxiv a license to display the preprint in perpetuity. It is made available under a CC-BY-NC 4.0 International license.

Figure 4 highlights the relapsing remitting nature of LCS reported over time between 13 to 31 weeks with maximum symptoms reported between 25 to 26 weeks, which is consistent with other research ${ }^{1,5,7,12,17}$. In figure 5, it is apparent that there was little difference noted between the cardio-respiratory function variables measured for PACS and LCS survivors. In terms of functional limitations, it is clear from Figure 6, that people with LCS had more functional limitations when compared with all ACS.

Overall, this study found that age $(<30$ years); rural geographic residence; housewife role or private sector occupation; one or more comorbidities; smoking; a longer acute COVID recovery period, a positive Rhesus factor in the blood group and prior functional limitations were all predictive risk factors for LCS. To our awareness, this is the first study to identify specific risk factors for Long COVID within the general population and whilst the specific context is Bangladesh, we think that these risk factors warrant further investigation in all global community populations.

Previous studies on Long COVID in Bangladesh focused on urban areas and did not include rural regions, as this study did, which is now identified as a risk factor Whilst males (m) comprised the majority of respondents with LCS (69.0\%), it was the females (f) who reported a greater proportion of LCS, (over all $\mathrm{f}=25.2 \%, \mathrm{~m}=21.2 \%$ ). This may be due to the overall higher incidence of COVID-19 diagnosed and reported by men in Bangladesh and the lack of sex disaggregated data in previous studies. The female sex was significantly associated with a longer duration of COVID symptoms. In addition, women reported slightly higher levels of fatigue, followed by pain, anosmia, and insomnia ( $\mathrm{f}=1.3 \%, \mathrm{~m}=0.3 \%$;). In contrast, men reported slightly higher levels of dyspnea, ageusia, cough and chest pain.

A significant positive association was found between gender and functional limitations. Women and those with cardio-respiratory comorbidity were more likely to develop functional limitations during the Long COVID period. In contrast, men and those with mild COVID symptoms were inversely associated with functional limitations.

The limitations of this study include that the sample was taken from twenty-four testing centres, and it is appreciated that people, who have attended these centres for diagnosis may not be truly representative of all communities within the Bangladeshi population. However, it will be possible for the team to contact and follow up on this cohort for longitudinal data in the future. In addition, the limited nature of resources meant that a proportion of potential 
medRxiv preprint doi: https://doi.org/10.1101/2021.07.03.21259626; this version posted July 6, 2021. The copyright holder for this preprint (which was not certified by peer review) is the author/funder, who has granted medRxiv a license to display the preprint in perpetuity. It is made available under a CC-BY-NC 4.0 International license.

participants could not be contacted due to system and educational constraints and the researchers had limited access to the electronic database. The LCS in this study were described by the survivors and screened by the data collectors, who were medical students. A clinical screening by healthcare professionals might reveal more in-depth symptom responses.

\section{Conclusion}

In this study, the prevalence of LCS was identified to be $22.5 \%$ at 4 weeks and $16.1 \%$ at 12 weeks post diagnosis. In addition, the study identified some key predictors for the presence of LCS, in terms of associated risk factors and also risk factors associated with a longer duration of Long COVID illness. Further research is needed to gain more insight into these identified risk factors and what can be done to support communities affected by it.

\section{Contributors}

MAH, KMAH, KS, ZU, LMW, VR, MS, RS, MSH, MFK, RF, SR, MSA, SKC, MAH, IKJ conceptualised the study. MAH, KMAH, LMW, VR, RS, SR, MSA, IKJ curated and collated the data. MAH, KMAH, KS, ZU, LMW, VR, MS, RS, MSH, MFK, RF, SR, MSA, SKC, MAH, IKJ did validation. KMAH, KS, ZU, LMW, VR, MS RS, SR, MSA visualised the data. MAH, KMAH, KS, ZU, LMW, VR, MS, RS, MSH, MFK, RF, SR, MAH, IKJ contributed to the model development. MAH, KMAH, KS, MS, RS, RF, SR, MSA, IKJ did the formal analysis. MAH, KMAH, KS, LMW, VR, RS wrote the manuscript. KS, ZU, LMW, VR, MS, MSH, MFK, RF, SR, MSA, SKC, MAH, IJK reviewed the manuscript. All author had full access to all the data in the study and the corresponding author had final responsibility for the decision to submit for publication.

\section{Ethical approval}

Ethical permission was obtained from the Institutional Review Board at the Institute of Physiotherapy, Rehabilitation, and Research (Ethical review committee at Bangladesh Physiotherapy Association) on September 17, 2020 (BPA-IPRR/IRB/17/09/2020/028) and the study was registered at World Health Organization (WHO)Primary Clinical trial registry platform (CTRI/2020/09/028165) on 30/09/2020 with the title "Symptoms presentation among the COVID-19 survivors in Bangladesh". Written approval for data collection obtained from the Directorate General of Health Services (DGHS) of the Ministry of Health and Family Welfare in Bangladesh. Verbal consent was obtained during the initial telephone 
medRxiv preprint doi: https://doi.org/10.1101/2021.07.03.21259626; this version posted July 6 , 2021. The copyright holder for this preprint (which was not certified by peer review) is the author/funder, who has granted medRxiv a license to display the preprint in perpetuity. It is made available under a CC-BY-NC 4.0 International license .

call and written consent was obtained at interview. The principles of the Helsinki Declaration ${ }^{19}$ were followed throughout the research to ensure confidentiality, ethics and privacy.

\section{Declaration of interests}

We declare no competing interests.

\section{Data Sharing}

All data collected in this study is confidential to the study and will be shared anonymously or following ethical principle and made available to others according to the necessity of the study. Data will be available at a public repository.

(https://www.kaggle.com/kmamranhossain/long-covid-bd).

\section{Acknowledgments}

We thank all individuals who participated in this study and their families.

\section{References}

1. Nalbandian A, Sehgal K, Gupta A et al. Post-acute COVID-19 syndrome. Nature Medicine. Vol. 27. April 2021. 601-615.https://doi.org/10.1038/s41591-021-01283-Z

2. NICE (National Institute for Health and Care Excellence). COVID-19 rapid guideline: managing the long-term effects of COVID-19. NICE guideline. Published: 18 December 2020. Accessed online June 2021.https://www.nice.org.uk/guidance/ng188

3. Perego E, Callard F, Stras L et al. Why the Patient-Made Term 'Long Covid' is needed [version 1; peer review: 1 approved with reservations, 1 not approved]. First published: 24 Sep 2020, 5:224Accessed online June 2021 https://wellcomeopenresearch.org/articles/5-224

4. Ayoubkhani D, Khunti K, Nafilyan V et al.Post-covid syndrome in individuals admitted to hospital with covid-19: retrospective cohort study. BMJ 2021;372: n693. Published online 15 March 2021. Accessed online June 2021.http://dx.doi.org/10.1136/bmj.n693

5. Kondratiuk A, Pillay T, Kon $\mathrm{O}$ et al. A conceptual framework to accelerate the clinical impact of evolving research into long COVID. Lancet Infect Dis 2021 Published Online April 22, 2021 https://doi.org/10.1016/S1473-3099(21)00136-5

6. Huang C, Huang L, Wang Y et al. 6-month consequences of COVID-19 in patients discharged from hospital: a cohort study. Lancet2021; 397: 220-32. Published Online January 8, 2021 https://doi.org/10.1016/S0140-6736(20)32656-8. Accessed online June 2021. 
medRxiv preprint doi: https://doi.org/10.1101/2021.07.03.21259626; this version posted July 6, 2021. The copyright holder for this preprint (which was not certified by peer review) is the author/funder, who has granted medRxiv a license to display the preprint in perpetuity. It is made available under a CC-BY-NC 4.0 International license.

7. Fernández-de-las-Peñas C, Palacios-Ceña D, Gómez-Mayordomo V et al. Defining Post-COVID Symptoms (Post-Acute COVID, Long COVID, Persistent Post-COVID): An Integrative Classification. Int. J. Environ. Res. Public Health 2021, 18, 2621. https://doi.org/10.3390/ijerph18052621

8. Nabavi N. Long covid: How to define it and how to manage it. The BMJ.

BMJ 2020;370:m3489. http://dx.doi.org/10.1136/bmj.m3489 Published: 07 September 2020. Accessed online June 2021.

9. Office for National Statistics. Prevalence of ongoing symptoms following Coronavirus (COVID-19) infection in the UK: 1 April 2021. Accessed online June 2021.https://www.ons.gov.uk/peoplepopulationandcommunity/healthandsocialcare/condi tionsanddiseases/bulletins/prevalenceofongoingsymptomsfollowingcoronaviruscovid19i nfectionintheuk/1april2021

10. Marx V. Scientists set out to connect the dots on long Covid. Nature Methods Published online: 28 April 2021 https://doi.org/10.1038/s41592-021-01145-Z

11. Carson G and Long Covid Forum Group. Research priorities for Long Covid: refined through an international multi-stakeholder forum. BMC Medicine (2021) 19:84https://doi.org/10.1186/s12916-021-01947-0

12. Greenhalgh T, Knight M, A'Court $\mathrm{C}$ et al. Management of post-acute covid-19 in primary care. BMJ 2020;370:m3026.Accessed online June 2021 https://www.bmj.com/content/370/bmj.m3026

13. Iwu CJ, Iwu CD and Wiysonge CS. The occurrence of long COVID: a rapid review. Pan African Medical Journal. Published 20 Jan 2021: 38(65). https://doi.org/10.11604/pamj.2021.38.65.27366.

14. Bangladesh Population (Live) Accessed via Worldometer website June 2021.https://www.worldometers.info/world-population/bangladesh-population/

15. Islam M, Ferdous M, Islam U et al. Treatment, Persistent Symptoms, and Depression in People Infected with COVID-19 in Bangladesh. Int. J. Environ. Res. Public Health 2021, 18, 1453. Accessed online June 2021.https://doi.org/10.3390/ijerph18041453

16. Mahmud R, Rahman MM, Rassel MA et al. Post-COVID-19 syndrome among symptomatic COVID-19 patients: A prospective cohort study in a tertiary care center of Bangladesh.PLoS ONE April 08 2021. 16 (4): e0249644. Accessed online June 2021.https://doi.org/10.1371/journal.pone.0249644

17. Cleveland Clinic Website. Accessed onlineJune2021.https://my.clevelandclinic.org/health/diagnostics/21462-covid-19-andpcr-testing 
medRxiv preprint doi: https://doi.org/10.1101/2021.07.03.21259626; this version posted July 6 , 2021. The copyright holder for this preprint (which was not certified by peer review) is the author/funder, who has granted medRxiv a license to display the preprint in perpetuity. It is made available under a CC-BY-NC 4.0 International license.

18. World Health Organization (WHO) Health Emergency Dashboard.Bangladesh. WHO (COVID-19) Homepage.Accessed online June 2021.https://covid19.who.int/region/searo/country/bd

19. The World Medical Association. WMA Declaration of Helsinki. Ethical Principles for Medical Research Involving Human Subjects. Accessed online June 2021. Available from: https://www.wma.net/policies-post/wma-declaration-of-helsinki-ethical-principlesfor-medical-research-involving-human-subjects/

20. Vandenbroucke JP, von Elm E, Altman DG et al. Strengthening the Reporting of Observational Studies in Epidemiology (STROBE): Explanation and Elaboration.PLoS Med. 2007. 4(10): e297.https://doi.org/10.1371/journal.pmed.0040297

21. Klok F, Boon G, Barco S, Endres M, Geelhoed J, Knauss S et al. The Post-COVID-19 Functional Status scale: a tool to measure functional status over time after COVID-19. European Respiratory Journal. 2020;56(1):2001494.

22. Machado F, Meys R, Delbressine J, Vaes A, Goërtz Y, van Herck M et al. Construct validity of the Post-COVID-19 Functional Status Scale in adult subjects with COVID19. Health and Quality of Life Outcomes. 2021;19(1).

23. World Health Organization (WHO). Process of translation and adaptation of instruments. Online guidance. Website accessed June 2021.https://www.who.int/substance_abuse/research_tools/translation/en/

24. World Health Organization (WHO). Working Group on the Clinical Characterisation andManagement of COVID-19 infection. A minimal common outcome measure set for COVID-19 clinical research. Lancet Infect Dis. 2020 Aug;20(8):e192-e197.doi: 10.1016/S1473-3099(20)30483-7. Epub 2020 Jun 12. Erratum in: Lancet Infect Dis. 2020 Oct;20(10):e250. PMID: 32539990; PMCID: PMC7292605.

25. Stavem K, Ghanima W, Olsen MK, et al. Persistent symptoms 1.5 - 6 months after COVID-19 in non-hospitalised subjects: a population-based cohort study, Thorax 2021,.76:405-407 doi:10.1136/thoraxjnl-2020-216377

26. Carfì A, Bernabei R, Landi F for the Gemelli Against COVID-19 Post-Acute Care Study Group. Persistent Symptoms in Patients After Acute COVID19. JAMA. 2020;324(6):603-605. doi:10.1001/jama.202027.

27. Logue J, Franko $\mathrm{N}$ and McCulloch D et al. Sequelae in Adults at 6 Months After COVID-19 infection. JAMA Network Open. 2021;4 (2): e210830.doi:10.1001/jamanetworkopen.2021.0830

28. Halpin SJ, McIvor C, Wyatt $\mathrm{G}$ et al. Post discharge symptoms and rehabilitation needs in survivors of COVID-19 infection: A cross-sectional evaluation. J Med Virol. 2021;93:1013-1022. doi: 10.1002/jmv.26368. Epub 2020 Aug 17 
medRxiv preprint doi: https://doi.org/10.1101/2021.07.03.21259626; this version posted July 6,2021 . The copyright holder for this preprint (which was not certified by peer review) is the author/funder, who has granted medRxiv a license to display the preprint in perpetuity. It is made available under a CC-BY-NC 4.0 International license.

29. SudreC, Murray B and Varsavsky $\mathrm{T}$ et al. Attributes and predictors of long COVID. Nature Medicine. 20212021 Apr;27(4):626-631. doi: 10.1038/s41591-021-01292-y Epub 2021 Mar 10.

30. Augustin M, Shommers P, Stecher M et al. Post-COVID syndrome in non-hospitalised patients with COVID-19: a longitudinal prospective cohort study. The Lancet Regional Health Europe (6) 2021 100122.DOI: https://doi.org/10.1016/j.lanepe.2021.100122 